\title{
Arabic codes in Hebrew texts: on the typology of literary code-switching
}

\begin{abstract}
In the late 1950s, Iraqi Jews left or had to leave Iraq for Israel. In the course of their encounter with a new society, with Hebrew as the national language, most Iraqi Jewish authors found it impossible to continue writing in Arabic in Israel and had to face the literary challenge of switching to Hebrew. As bilinguals, Iraqi Jewish novelists have employed Arabic in some of their Hebrew literary works, including code-switching. Conversational Code-switching is traditionally divided into three types: intersentential code-switching, intrasentential code-switching and tag-switching. Although codeswitching in literary texts has its distinct features, research on written code-switching generally follows the typology applied to conversational code-switching. This paper focuses on the typology of code-switching in literary texts. It investigates Arabic codes used in three Hebrew novels written by Iraqi Jewish novelists. The paper suggests three main types of literary code-switching in view of the mutual relationship between author, text and reader. These are Hard-Access, Easy-Access and Ambiguous Access codeswitching.
\end{abstract}

\section{Keywords}

bilingualism; bilingual authors; exophonic texts; written code-switching; Hebrew;

Arabic 


\section{Introduction}

\section{Exophonic texts and bilingual authors}

Few attempts had been made to describe the phenomenon of writing literature in a language other than one's mother tongue. One of the earliest observations by Haugen (1953) refers to bilingual authors as "mixing" in some Norwegian literary works, where the term "mixing" refers to some English words inserted into works of fiction. Kellman (2000:ix) describes authors who 'write in more than one language or at least in a language other than their primary one' as translingual authors. According to Kellman, the phenomenon of translingualism is initiated by the combination of "colonialism, war, increased mobility, and the aesthetics of alienation" (2000:7).

One more concept used in defining literary texts written by bilingual authors is exophony which refers to the writing of literature using a non-mother tongue (Heinrichs 1992). The idea of exophonic perception derives from a study of a group of African writers who write in adopted European languages, mainly French (Heinrichs 1992). The concept was later used by Wright (2010) as a tool by which translators should approach such texts. Exophonic writers write literature in a non-mother tongue, which is associated with authors who live in bilingual/multilingual communities or with immigrant authors who adopt a new language while in voluntary or mandatory exile. This is also the case with the three Iraqi Jewish authors discussed here; i.e. they write in Modern Hebrew, the adopted language in their new homeland, and not in Arabic, their mother tongue.

The language strategies used by exophonic authors is actually the result of their attempt to establish connections to the cultural backgrounds from which they come. This is one of the salient aspects of post-colonial literature in which the conflict 
between adapting to and refusing some linguistic norms signifies the nature of that kind of writing (Ashcroft et al. 2003:38). In addition, writing that draws on two or more linguistic backgrounds offers authors possibilities that differentiates their literary work to some extent from other monolingual authors in terms of linguistic, metaphoric and stylistic qualities:

Having two languages has some kind of cognitive effect, opening up new possibilities, making the writer aware of the mechanics of language, providing literary inspiration; and finally, that writers, on the whole, write to be read and to be listened to, and that the relevant, and perhaps even the wider audience for one's texts may not be that of one's mother tongue. (Wright 2010:24)

Given that exophonic texts are produced by bilingual authors, an explanation of the concept of 'bilingual author' is opportune. Grosjean (2010) divides bilingual authors into three main types: (1) authors who write only in their mother tongue; (2) authors who write in their second or third language; and (3) those who write in two languages. Grosjean adds that the third type of writer may use two languages within the same literary piece of work (2010:134-44). Grosjean (2013:22) also analyzes bilinguals with experiences in two cultures, what he terms "bicultural bilingual", such as immigrants, i.e. people who often acquire the language alongside the culture of the new land. Thereby they are expected to have two cultural experiences and two languages, one belonging to the homeland and the other language adopted in the new land. A bilingual's ability to perceive words in two languages, particularly those that hold cultural patterns, requires cultural experience together with language competence (Grosjean et al. 2013:23). Grosjean (2013:21-24) compares the ability of a bicultural bilingual to "monoculture bilinguals" (who do not have the cultural background to differentiate between some lexical items associated with certain cultural patterns), confirming the difference between the two. 


\section{The authors and their Hebrew novels}

In the aftermath of the mass immigration of Jews from Arab lands to Israel during the 1950s, Iraqi Jewish writers, like other immigrants to Israel, experienced certain difficulties and hardships during the first years after their arrival (1950-1951). The first obstacle they faced in the integration process into the new society was learning its language, Hebrew. Since the three authors -Sami Michael (born in Baghdad in 1926), Shimon Ballas (born in Baghdad in 1930) and Eli Amir (born in Baghdad in 1937) - left Iraq as young adults during the 1950s where Arabic was their mother tongue, they had to rebuild their lives in a country that was completely new and in many ways foreign to them. Furthermore, after their immigration to Israel, these Iraqi Jewish authors had to begin to write in Hebrew in order to be read by Israeli readership.

Since it was difficult to find empathetic listeners to his silenced voice, Michael (1984:23) tried to find a solution: "I was ready to learn new things, but I categorically refused to break with my former self. The upshot of this was that Israeli society was not prepared to listen, and I was unable to make myself heard -I had no Hebrew then". Not only Michael, but also Ballas, who both wrote in Arabic at the beginning of their literary careers in Israel before switching to Hebrew, understood the importance of acquiring the Hebrew language. The same holds true for Amir, who started writing directly in Hebrew.

The first Hebrew novel written by an Iraqi Jewish author was published in 1964: $\mathrm{Ha}$ ma 'barah (The Transit Camp) by Shimon Ballas (1964). A decade later this was followed by Sami Michael's Shavim we-shavim yoter (All Men are Equal - but Some Are More) (1974) and in 1983 Eli Amir published his debut novel Tarnegol Kapparot (Scapegoat) (Amir 1983). These first Hebrew texts have protagonists brought from 
Baghdad and represent its landscapes and surroundings. They depict Iraq through literary characters who express longing for their home country. Mainly autobiographical, the recollection of the experience of pre- and post-immigration to Israel occupies a considerable part of the works. Through their writing they try to come to terms with their past and present, with Arabic and Hebrew, in order to find a bridge between the two. Ballas clearly admits the influence of Arabic on his writing: "I am in dialogue with language itself [Hebrew]. On the one hand, I am trying to fend off, avoid or neutralize ideological connections or associations with the language. On the other hand, I think that I am probably trying to bring my Hebrew closer and closer to Arabic" (Alcalay 1996:68).

It is worth mentioning that the Arabic variety used by the Jews of Baghdad, and hence by the Iraqi Jewish authors before they immigrated to Israel, is Baghdadi JudeoArabic. In general, the Iraqi Judeo-Arabic was spoken mainly by Jews at home in Iraq, this vernacular was different, in terms of some phonological and lexical aspects, from other Arabic dialects spoken by both Muslims and Christians in Iraq (Blanc 1964). As for the literary contributions of Iraqi Jews in modern times, the majority of Iraqi Jewish writers, for instance, preferred to compose poetry and fiction in Modern Standard Arabic (Snir 2005a:79-134). However, Jewish folklore writings flourished and were written in Iraqi Judeo-Arabic from the mid-nineteenth century. The folklore literature of Judeo-Arabic written by Iraqi Jews can be divided into three categories: 1) Translations and copies from Jewish sources, 2) Translations and copies from foreign sources, and 3) Local folklores written by Iraqi Jews themselves (Avishur 1979:84-86). ${ }^{1}$

\footnotetext{
${ }^{1}$ For more information about the Judeo-Arabic of Iraqi Jews, see (Avishur 2008-2010); (Mansour 1991); (Ben-Jacob 1998); (Me'iri 2006) and (Yosef 2005). For general information about the Judeo-Arabic linguistic features, see (Blau 1981) and (Hary 1992).
} 
Most of the studies done concerning the three Iraqi Jewish authors follow mainstream literary socio-political approaches, including: (Alcalay 1993, 1996; Berg 1996, 2005; Hever 2002, 2007; Hever et al. 2002; Levy 2006; Müller et al. 2011; Snir 2005a; Snir 2005b). Yet if the three authors and their literature are not examined in the light of sociolinguistics, an important aspect of their creation is overlooked. This paper focuses on the use of Arabic codes in these early Hebrew novels, asserting that Arabic used in the three novels employs a sociolinguistic phenomenon, namely code-switching. The study discusses the typology of conversational code-switching in general and in written discourse in particular.

\section{Code-switching in written discourse}

Code-switching (CS) is one of the most common phenomena resulting from languages in contact, deriving from a bilingual/multilingual context where people communicate by means of more than one language or dialect due to their linguistic background. Early research into the term was developed by Jakobson (1956) in his work on language contact. Poplack's early research suggested defining CS as "the alternation of two languages within a single discourse, sentence or constituent" (1980:583). She also discussed the possibility of employing CS as a tool to determine the language competence of a bilingual. Many recent studies take a closer look at the idea of CS. Myers-Scotton (1993:1) defines CS as "the term used to identify the alternations of linguistic varieties within the same conversation". The Cambridge Handbook of Linguistic Code-switching defines it more generally as "the ability on the part of bilinguals to alternate effortlessly between their two languages" (Bullock \& Toribio 2009). 
Studies on the phenomenon of CS distinguish between three main types: “intersentential", “intrasentential” and "tag-switching" (Poplack 1980:589). According to Poplack, tag-switching refers to the use of tags repeated by a bilingual, particularly in ethnic contexts. She adds that since they are grammatically detachable in a sentence, these kinds of switches are highly used compared to the other two types: "Tags are freely moveable constituents which may be inserted almost anywhere in the sentence without fear of violating any grammatical rule" (1980:589). Examples of such tags are the interjections/exclamations that come before a sentence or before a whole text (Appel \& Muysken 2005:118).

Intersentential CS is the act of switching codes between sentences and clauses or "at a sentence boundary" as Thomason (2001:132) puts it, while intrasentential CS, or code-mixing (Muysken 2000), occurs within the sentence itself and is more complicated than the other two types. This is due to the strong possibility that linguistic interferences may be involved during the process of code-switching. Interference settings with this type of switch involve morphological, syntactic and phonological levels.

\section{On the typology of written code-switching}

\section{Toward a new perspective}

Research into CS at spoken level is based on solid quantitative and qualitative studies. At the level of interactive language contact (spoken/conversational), the phenomenon is both well studied and categorized (CS, borrowing, code mixing, pidgin and Creole). However, few studies are concerned with the CS phenomena at written level, e.g. (Callahan 2004; Ibhawaegbele \& Edokpayi 2012; Jonsson 2010; Montes-Alcala 2000, 2012; Sebba et al. 2012; Torres 2007). 
The attempts to describe the strategies for employing codes in a literary text that are outside the dominant language, include an insightful study by Torres (2007) on CS strategies used by Latino/a writers. Torres sees the strategies of using Spanish in English Latino/a texts as (1) easily accessible codes, i.e. the use of Spanish lexical items with a clear meaning that is comprehensible from the context; and (2) the translation of Spanish words and phrases into English. In view of this the categorization of the cases of CS in the three Hebrew novels that are the subject of this paper relies on the mutual relationship between three main elements: the author, the text and the reader. The following section discusses these categories in connection to these three elements.

With regards to, first, the author, the CS in interactive modes (spoken CS) is likely to be more spur-of-the-moment and the participants in the bilingual conversation are only slightly aware of it (Shanon 1991; Gardner-Chloros 2009), although the use of register or code variation may undergo a 'stylization' during the time of the conversation (Coupland 2001a; Coupland 2001b). The same perhaps does not hold true for the literary text, where less time is spent choosing the codes in the conversations, than when the bilingual author is writing the manuscript (Lipski 1982:192). The author has both the time and opportunity to edit and review what s/he has written. One should also consider the role of the editor. His or her task is mainly to maintain the general canon and repertoire of a given literary form of expression. In general, the act of written CS in the literary genres is more subject to conscious practices and less dependent on accidental and more spontaneous linguistic behaviour.

Concerning the text and audience, this paper draws on Jakobson's model for the factors involved in verbal communication (1960:353). In this context, the "addresser" is the author/writer of the text, while the "addressee" is, accordingly, the reader. The text 
acts as the contact or physical channel by which the message (which is structured via codes that are familiar to both author and reader) is carried. The code, according to Jakobson (1960:353) must be "fully, or at least partially, common to the addressee". This paper examines some Arabic codes employed by the three Iraqi Jewish authors in the Hebrew texts in light of their familiarity and degree of commonality for readers who have neither a linguistic nor cultural Arabic background.

Given that an author's decisions and intentions are both involved in the process of inserting codes from outside the Matrix Text Language (MTL, here Hebrew) as well as interpreting the text as a message that requires a decoding process, as discussed above, this study divides literary code-switching into two main types: Hard-Access CodeSwitching (HA-CS) and Easy-Access Code-Switching (EA-CS). The former refers to any code added by the author that does not belong to the MTL and may be expected to create difficulties for any reader who does not share the author's bilingual and bicultural linguistic background (an outsider reader, or Out.R). On the other hand, EA-CS is the insertion of non-MTL codes by the author, who tries to elucidate these codes so as to make them decodable to the Out.R. The strategies available to the bilingual author in this case are varied and include direct translation, footnotes and glossing the foreign codes using the MTL.

\section{Notes on categories:}

1 Since tag-switching largely involves words (like the interjections/exclamations that come before the sentence), the author does not need to work as hard to interpret them to make them decodable as with the other two types of code-switching (inter/intrasentential code switching). Additionally, tag-switching is much more popular in bilingual communities when compared to inter-/intrasentential code-switching. In 
view of this, tag-switching may be easy and/or difficult to access, depending on the sociolinguistic aspects of the reader's community. Therefore, this study suggests the term Ambiguous-Access Code-Switching (AA-CS) to replace the term tagswitching.

2 The accessibility of code switches in bilingual literary texts is relative. It depends on the individual reader and/or the community of readers in which one reader's linguistic background is not identical to another's and the bilingualism in one community is not as strong as in another.

3 In view of the mutual relationship between the reader and the author via the text, the study divides the readers into insider reader (In.R) and outsider reader (Out.R). In.R refers to the reader who shares the same linguistic and cultural background as the author regarding all the codes employed in the text. The Out.R, accordingly, is a reader who cannot comprehend as well as the In.R, at least to some extent, the codes of the embedded language in the text. The categories of foreign codes employed by the author are, then, applied to the Out.R because the In.R has full access to the text's codes.

4 The matrix Text Language (MTL) refers here to the dominant language in which the text is written. Although the term is similar to the term used in the Matrix language frame model (MFL) developed by Myers-Scotton (1998) in her research on conversational code-switching, this study does not use the concept of Matrix and Embedded language in view of the (MFL). The MTL and the Embedded Language (EL) terms used in the present study, however, are connected to the linguistic background of the author and the reader as explained above in note (3). 
5 The Iraqi Jewish authors and the texts selected for this study constitute a case of exophonic authors and the way in which they employ codes from their mother tongue in the exophonic texts. In general, the model developed by this study could be applied to investigate code-switching phenomenon in any exophonic texts regardless the languages involved.

\section{Arabic codes in the three Hebrew novels}

\section{The data}

The first three Hebrew novels written by the three authors constitute the data under investigation. ${ }^{2}$ For the purposes of precision, only Hard-Access Code-Switching and Easy-Access Code-Switching are counted. Ambiguous-Access Code-Switching terms are excluded from the count. This is due to the ambiguity associated with this type of code, which makes them impossible to verify precisely.

\section{Numerical results}

Arabic codes are used instead of Hebrew codes by all three Iraqi Jewish authors. Arabic words and sentences are written in Hebrew transcripts. The following table presents the word counts for HA-CS and EA-CS according to each novel.

\footnotetext{
${ }^{2}$ The data used in the analysis is extracted manually from the text. The corpora are not digitalized, so the frequencies stated in the study cannot be $100 \%$ guaranteed, although there is a great effort in the study to ensure the accuracy of the results.
} 
Table 1. ${ }^{3}$

\begin{tabular}{lcc}
\hline Novel & HA-CS & EA-CS \\
\hline Ha-Ma barah (The Transit Camp) (Ballas 1964) & 44 & 31 \\
$\begin{array}{l}\text { Shavim we-shavim yoter (All Men are Equal - but Some } \\
\text { are More) (Michael 1974) }\end{array}$ & 216 & - \\
Tarnegol kapparot (Scapegoat) (Amir 1983) & 107 & 29 \\
Total & $\mathbf{3 6 7}$ & $\mathbf{6 0}$ \\
\hline
\end{tabular}

HA-CS: Hard-Access Code-Switching

EA-CS: Easy-Access Code-Switching

Looking at the Arabic codes used in the Hebrew novels, the overall sum of HA-CS is 367, whereas the total number of EA-CS is only 60 . This means that of the total number of Arabic codes implemented in the three Hebrew novels, approximately $86 \%$ are HACS and about $14 \%$ are EA-CS. In all the novels, HA-CS is the most-used code. This indicates the extent to which the Arabic codes, which are combined into sentences or stand alone in lexical items, would be hard to access or sometimes non-decodable for an Out.R. The attitude of the three authors toward some Arabic codes -making them only decodable by an In.R-has two functions, one literary and the other sociological. The former is related to the stylistic devices that the non-decodable Arabic codes bring to the Hebrew texts, thereby reflecting the literary style of the Iraqi Jewish authors in the canon of modern Hebrew literature, while the latter confirms the linguistic and ethnic sense of belonging on the part of the authors not only to Israel but also to Arab and Iraqi culture.

\section{Hard-Access Code-Switching}

All three authors also use some Arabic codes in the Hebrew texts without interpreting them to make them easily accessible for an Out.R. Playing with Arabic in this way has

\footnotetext{
${ }^{3}$ For the complete list of code-switching extracts, see the appendixes.
} 
stylistic function for the Hebrew texts, introducing the reader to the Arabic and Iraqi bilingual speakers/characters at the dialogue level. Here some interference between Arabic and Hebrew is expected. Given that the hard-to-access codes require a bilingual reader (In.R), the more HA-CS used in the text, the more bilingual the text. The two main types of conversational code-switching (inter-/intrasentential) are used in the Hebrew texts as shown in the following abstracts.

Intersentential Code-Switching Michael (1974) uses intersentential code-switching in the following dialogue. In order to make the conversation more realistic, Michael uses complete Arabic sentences and clauses alongside Hebrew sentences. The reason for using Arabic codes in the plot here is to defraud the Egyptian soldiers by using the same dialect they speak so as to hide the character's Israeli identity and save him from being killed in the war in Sinai. The HACS here interrupts the message, which only an In.R can decode.

Extract $1:^{4}$

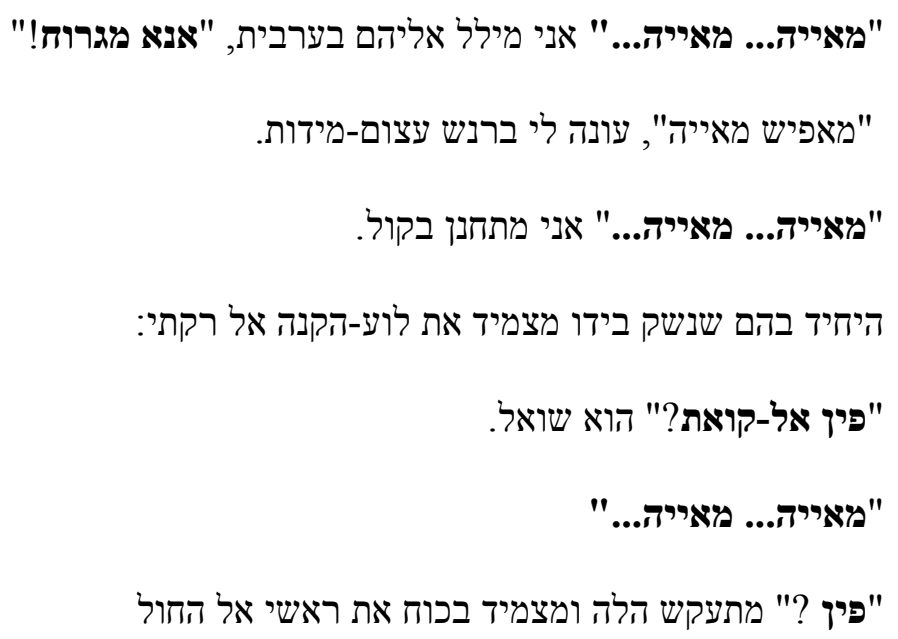

\footnotetext{
"mayya... mayya..." 'ani meyallel 'alehem b-'aravit, " 'ana mă̆ruh!"

"mafiš mayya”, 'one li barnaš 'acum middot
}

\footnotetext{
${ }^{4}$ All Arabic codes in the paper appear in bold.
} 
"mayya... mayya..." 'ani mithannen be-qol.

hayahid ba-hem še-nešeq be-yado macmid 'et lu'a ha-qane 'el raqqati:

“fen el-quwwat?” hu šo'el.

"mayya... mayya..."

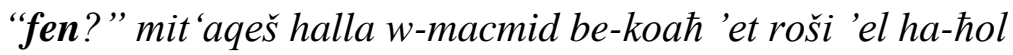

"hunak" 'ani macbi 'a be-yadi klape hevheqe ha-totahim

، "Water...water" I howl to them in Arabic, "I am injured". 5

"No water", answered me a huge guy.

"Water...Water" I am begging loudly

The only one of them who was carrying a gun shoves the barrel of a gun to my temple.

"Where are the forces?" he asks.

"Water... Water...".

"Where? He insists while shoving my head firmly down to the sand

"Out there!" I point with my hand to the flare of the field guns.'

(Michael 1974:191)

Intrasentential Code-Switching

Unlike intersentential code switching, intrasentential code switching (or code-mixing) is more integrated within the dominant language of a text (here Hebrew).

Extract 2:

אללה יבארפ פיפ על הקפה הזה

'allah yebarek fik 'al ha-qafe ha-ze.

\footnotetext{
${ }^{5}$ All English translations of the Hebrew extracts were done by the author of the article.
} 
'God bless you for the coffe (For making the coffe for me).'

(Amir 1983:148)

The sentence is an extract from a dialogue between Nuri, the narrator, and Salim. The sentence begins with Arabic codes and ends with Hebrew codes, which are mixed together here and integrated to construct the sentence.

Extract 3:

ביום הלימודים הראשון חטף "פאלקות" על כפות רגליו

be-yom ha-limmudim harišon ћațaf falakot 'al kappot raglav.

'On the first day of school he received Falakot (Foot whipping) on his soles.'

(Amir 1983:69)

In these examples, the authors use intrasentential code-switching within the Hebrew sentences. Using Arabic in this way is very complicated because of the high possibility of interference between the two languages in the case of intrasentential code-switching. As to morphology, the above-mentioned example touches on the possible interference between Arabic and Hebrew. The term falakot constitutes an Arabic singular noun falaka that takes Hebrew plural /ot/ instead of using the Arabic form /at/. Conversely, the strategy of applying Arabic morphology to some Hebrew lexical items is one of Iraqi Judeo-Arabic features (Blanc 1964:146).

\section{Easy-Access Code-Switching}

In order to make the Arabic codes employed in the Hebrew texts accessible to more readers, Iraqi Jewish authors use two main strategies: (1) direct translation of Arabic words and phrases in the text and (2) glossing. What follows are some examples of EACS from the Hebrew texts. 


\section{Direct Translation}

The use of the strategy of direct translation with embedded Arabic lexical items and phrases is common in the Hebrew texts. Arabic lexical items (e.g. nouns, verbs, adjectives, pronouns and interjections) as well as Arabic phrases (e.g. verbal/ noun) are translated into Hebrew. The translation sometimes appears in the text directly after the Arabic, while in other cases it is footnoted. The wide range of translated Arabic lexical items and phrases reveals how Arabic is broadly used in the Hebrew texts.

Direct Translation - Lexical Items:

Extract 4, Arabic noun:

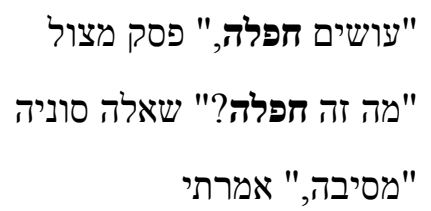

“'osim hafla,” pasaq macol.

“ma ze hafla?" ša'ala Sonja.

"mesibba," 'amarti.

'We are going to make a hafla ," decided Matsul.

What dose hafla mean? Sonia asked.

"Party," I said.'

(Amir 1983:106)

In this example the author inserted an unexpected Arabic code $\hbar$ afla into the Hebrew conversation held between Matsul, Sonia (the Ashkenazi leader in the Kibbutz) and the narrator. However, the Hebrew equivalent comes in the form of an answer to the question What does hafla mean? asked by Sonia. The same holds true for the following example, in which the author puts the direct translation in brackets after the Arabic code gaћba (Yona-Swery 1995:58). 
Extract 5, adjectives:

רק גחבה [זונה] חסרה לנו פה

raq gaћba [zona] hasera lanu po.

'Only a gahba [whore] we are missing here.'

(Amir 1983:124)

Direct Translation - Phrases.

The strategy of direct translation is also applied to both noun and verb phrases:

Extract 6, noun phrase:

אתה מספר לי? ...כמו א־שבּאבּ אל־קאוּמי* אצלנו

'atta mesapper li? kemo aš-šabab al-qawmi 'ecelenu

'You are telling me? (they are) like aš-šabab al-qawmi (the National Youth) of ours (in Iraq).'

Here Ballas uses the translation strategy to make the Arabic codes aš-šabab al-qawmi accessible. Ballas includes the translation as well as two lines of information about the historical context of aš-šabab al-qawmi in the footnotes:

* הנוער הלאומי-"ארגון נוער בעל נטיות ימניות־פשיסטיות שהיה קיים בעיראק בשנות הארבעים".

'National Youth - A youth organization with conservative-fascist tendencies that was active during the 1940s in Iraq.'

(Ballas 1964:11)

Extract 7, verbal phrase:

Unlike in extract 6, Eli Amir uses direct translation after Arabic codes. For instance, he puts the translation between brackets directly after the Arabic codes 'akun mamnun: 
'akun mamnun ['ehye 'asir toda]

'I would be grateful.'

(Amir 1983:148)

Glossing

In addition to the strategy of direct translation employed in the Hebrew texts, there is a strategy of explaining and elucidating some Arabic codes where direct translation is deemed insufficient to make these codes accessible. By using this strategy, the author attempts to explain embedded Arabic codes through the narrative or in the dialogues between the characters. This technique integrates the Arabic more fully into the Hebrew narrative instead of isolating it as in the HA-CS cases (see below).

Glossing can be done through the dialogue between the characters. Mrs. Zippora, an Ashkenazi woman, asks Abu Halawa, an Iraqi Jew, to elucidate the Arabic code (xazuq) during their conversation:

\section{Extract 8}

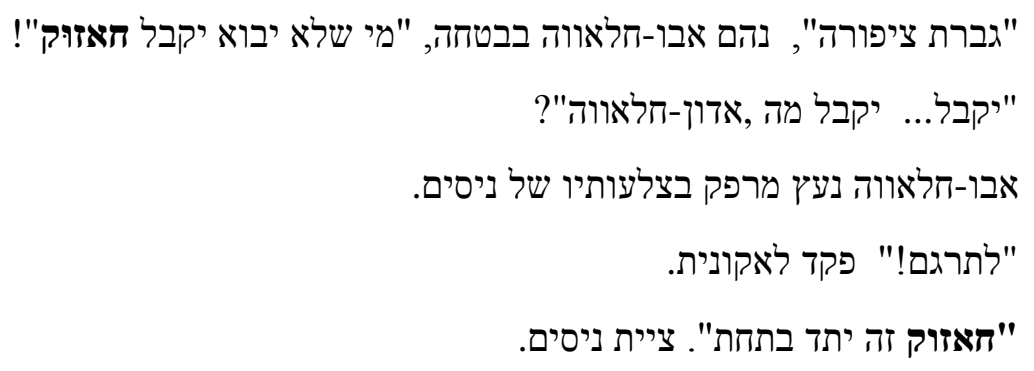

Geveret Zippora, naham 'abu-halawa be-vitha: "mi še-lo yavo yeqabbel xazuq," yeqabbel ... yeqabbel ma, 'adon halawa?

'abu-ћalawa na 'ac marpeq be-cal 'otav šel nisim

“le-targem!” paqad laqonit.

"xazuq ze yated ba-tahat" ciyet nisim 
'Mrs. Zippora", roared Abu Halawa , "whoever would not come would get a xazuq!

He would get... would get what Mr. Halawa?

Abu Halawa stabbed his elbow into Nisim's ribs.

“Translate!”commanded (Abu Halawa) laconically

"xazuq is a stake (inserted) in the bottom". Obeyed Nisim.'

(Michael 1974:78)

In the above example, the translation of the Arabic lexical item is glossed in the dialogue between two Iraqi Jews and an Ashkenazi woman. The humour Michael depicts in the interaction reflects Arabic/Hebrew linguistic conflicts.

\section{Ambiguous-Access Code-Switching}

The study uses the term "Ambiguous Access" to reflect the use of Arabic codes that are hard to translate into Hebrew, on the one hand, but can be understood through the Hebrew context in the novels, on the other. This type of code cannot be considered a HA-CS, because they can be elucidated within the content of the novel. Neither can they be seen as EA-CS as they are not, for the most part, translated within a Hebrew utterance. This study counts three main cases in which AA-CS is likely to occur: interjection, character and place names and word-for-word translation.

\section{Interjections}

Arabic interjections are frequently found in the Hebrew texts. Sometimes the use of such codes is followed by a translation and sometimes not. In Extract 9, Ballas inserts an Iraqi code into the dialogue between Nazima, an Iraqi Jewish woman, and Yusef Shabi. The code is not translated into Hebrew, but the context of the plot guides the reader to understand how this code, which conveys sadness, anger and sorrow, is probably being used: 
Extract 9:

נזימה התיפחה וטפחה על חזה. משראתה אותו פתחה בצעקה:

"הכל בגללך, יוסף! הכל בגללך... אתם הרסתם אותנו ! יאבוי..."

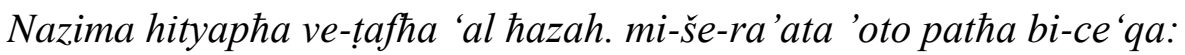

ha-kol bi-glalxa... 'attem harastem 'otanu...yabuy.

'Nazima weeped and struck her chest. When she saw him she began to cry:

"All of this is because of you, Yousef! All because of you...you have destroyed us! yabuy"',

(Ballas 1964:29)

The Arabic code here, yabuy, is not highlighted by the author to mark it as Arabic code and neither is the code translated into Hebrew in a footnote or the text. Yet, the plot, involving a fatigued Iraqi woman named Nazima who was crying, makes it clear to the reader that the Arabic code here is associated with anger and sorrow. Although the context in which the Arabic code is employed can assist an Out.R, its literary effect may not be perceived by an Out.R as well as it may be perceived by an In.R. This is because of the use of such vernacular code requires familiarity with Iraq and Arabic traditions. Thereby, such codes would target an In.R.

Characters and place names

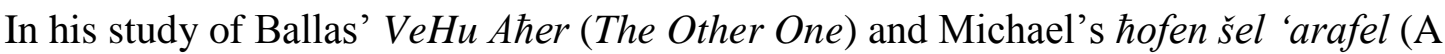
Handful of Fog), Zeidel (2009) raises the question of whether these two novels (both published in Israel and written in Hebrew) are Iraqi or Israeli. He uses the content of the novels as well as the themes and the language to show that these texts would need to be clarified by the authors to be more comprehensively understood by a non-Iraqi reader: 
The use of the vernacular, of cultural and political codes, and of a language that assumes familiarity with the landmarks described, would very often characterize those who target the Iraqi readership. For example, in such a novel there will be no need to describe and explain, like a tourist guide, about the monuments one sees when strolling between two points in central Baghdad. An Iraqi reader is familiar with them. Strangely, the two novels in Hebrew defy language barriers and are seemingly written to an Iraqi readership, that is, to readers who are already acquainted with the streets of Baghdad and the ins and outs of Iraqi history. (2009:231)

Some characters with Arabic names in the novels also represent AA-CA. Arabic names used by Iraqi Jewish authors reveal the cultural and historical patterns associated with Arabic and the Iraqi language. This connection between names and cultural backgrounds turns Arabic names into codes that constitute marked choices. Although the names are hard to translate, the context might help to explain the meaning and value of using such names. However, in many cases neither the translation, if any, nor the context can convey the meaning of these codes:

\section{Extract 10}

אמת. עלית על מחמוד אל־אערג'!

'emet. 'alita 'al maћmud al-'a'raj.

'Honestly you surpass Maћmud al-A rag.'

(Ballas 1964:146)

This compliment is expressed by one of the guests in the al-Nasr café house to Moše ha-Šomer, who has just finished a poem he wrote about the Ma'barah. ${ }^{6}$ His friend praises the poem and states that he is better than Maћmud al-A'rag. But, who is Mahmud al-A 'rag? And what type of poetry does he write? Even if the author provides

\footnotetext{
${ }^{6}$ Ma'barah (Hebrew: מעברה) was a transit camp for new Jewish immigrants in Israel during the 1950s. The Ma'barot (plural) were used as absorption camps providing accommodation for newcomers, mainly those arriving in Israel during the mass immigration of the Jews from Arab countries. For more information about the Ma'barot, see: (Naor 1986).
} 
some information about him in the footnotes (which he does not), is it possible to make the metaphoric dialogue here clearer to a reader who has not read al-A 'rag's poetry in Arabic? The answer to these questions suggests that some character and place names can be considered AA-CS.

This is also the case, for instance, with the term Karaxana šel Baghdad in Amir's novel, an example of the use of a Baghdadi place with local and historical connotations that makes the Out.R ask, what is Karaxana and what is the connection to Baghdad and Iraq and to the Jews in Iraq if any? The question: "what is this here, Karaxana of Baghdad?" (Amir 1983:58), is accusingly asked by the conservative mother of Florelantin (her Iraqi name: Farida), who is angry about the way her daughter Nora is dressed. The mother expresses her annoyance by asking the question, describing the kibbutz as Karakhana šel Baghdad, or "cabaret of Baghdad”. These examples, among others, invite the reader to contemplate Iraqi cultural and historical images. Although they are just names in an utterance, they create a bond between the author and a special group of his readers: the 'insider readers'.

Word-for-word translation

When a bilingual author translates an idiom or folk saying into the dominant language of the text, s/he wants to make the codes in this idiom more accessible to the Out.R. The translation, however, is not able to transfer the metaphorical sense of the origin of the idiom, as is expected in the case of a word-for-word translation of an embedded Arabic idioms or folk saying in a Hebrew text. Although the author's self-translation of the embedded codes contributes to making them easily accessible, at least at the utterance level, the difficulty in understanding their connotations probably makes them inaccessible. Therefore the term AA-CS may be applied to some of them: 


\section{Extract 11}

\section{תסאות אל גרעה ואום אל שער (הקירחת ומקורזלת השיער אותו דבר)}

tsawat al-gar 'a we-'um aš-ša 'er.

'A bald woman and a woman with hair are both the same.'

(Amir 1983:79)

In the translation, which is given by Amir in brackets, the metaphor in this idiom seems too unclear. In a reference to the translation, the metaphor the above idiom holds is not clear enough. The metaphoric connotation here is to wonder how two things, one of which is precious and valuable and the other is not that valuable, come together in one scale and are seen as one thing. The Arabic-Hebrew Dictionary of the Babylon Jewish Dialect (Yona-Swery 1995:109) presents a more enriched translation of this item:

"תסאות אל גרעה ואום-אל-שעע' (אימרה) - (בעלת הקרחת ובעלת השיער נהיו שוות) : העשיר והעני נראו זהים"

Here the authors of the dictionary thought that the word-for-word translation is not enough to transfer the Arabic code into Hebrew. ${ }^{7}$ Accordingly, they were keen on adding another gloss to help in understanding the Arabic message conveyed by the idiom: העשיר והעני נראו זהים (the rich and the poor men are seen as equals).

Other examples of this phenomenon include Arabic idioms used by Amir (Amir 1983:19, 66, 87, 201) and Ballas (Ballas 1964:52, 86, 125).

\footnotetext{
${ }^{7}$ See also the term explained in (Ben-Jacob 1998:932). For more examples of Iraqi Judeo-Arabic folk sayings, see (Me'iri 2006).
} 


\section{Conclusion}

While research into spoken code-switching divides the term into three main categories (intersentential code-switching, intrasentential code-switching and tag-switching), the study of code-switching in literary texts has its own paradigm. This paper analyzes code-switching in the context of the mutual relationship between author, text and reader. Accordingly, the study suggests that literary code-switching can be analyzed in light of two main types: Hard-Access Code-Switching (HA-CS), which includes intersentential code-switching and intrasentential code switching, and Easy-Access Code-Switching (EA-CS), which involves both direct translation and glossing. A third type is also put forward to apply to cultural patterns associated with the mother tongue: Ambiguous-Access Code-Switching (AA-CS).

The study shows that there are some cases in which the codes are elucidated by the author, although, at least in the literary sense, they remain un-decodable for some readers who do not share a linguistic and cultural background with the author (outsider reader, Out.R). This can apply, for instance, to the cases of word-for-word translation and the use of some character and place names. In contrast, there are also other codes that can be perceived by an Out.R (e.g. some interjections), although the author does not clarify them for that reader. Therefore, the study suggests the term AA-CS to describe, firstly, some codes that can be understood from the context of the text although they are HA-CS and, secondly, some cases of EA-CS that are difficult for an Out.R to understand despite the interpretations offered by the author to make them more accessible. 


\section{References}

Alcalay, Ammiel. 1993. After Jews and Arabs: Remaking Levantine Culture.

Minneapolis: University of Minnesota Press.

- 1996. Keys to the Garden: New Israeli Writing. San Francisco: City Lights

Books.

Amir, Eli. 1983. Scapegoat. Ofakim Library. Tel Aviv (in Hebrew).

Appel, René, \& Pieter Muysken. 2005. Language Contact and Bilingualism.

Amsterdam: Amsterdam University Press.

Ashcroft, Bill, Gareth Griffiths, \& Helen. Tiffin. 2003. The Empire Writes Back: Theory and Practice in Post-Colonial Literatures. 2 ed. London: Routledge.

Avishur, Y. 1979. "The folk literature of Iraqi Jews in Judeo-Arabic." Pe ámim 3: 83-90 (in Hebrew).

—.2008-2010. The Dictionary of the New Judeo-Arabic Written and Spoken in Iraq (1600-2000). 3 vols. Tel Aviv-Jaffa: Archaeological Center Publication (in Hebrew).

Ballas, Shimon. 1964. The Transit Camp. Tel Aviv: 'Am 'oved (in Hebrew).

Ben-Jacob, Abraham. 1998. Treasury of Proverbs of Iraqi Jews in the Last Era. Jerusalem: Yerid ha-sefarim (in Hebrew/ Judeo-Arabic).

Berg, Nancy E. 1996. Exile from Exile: Israeli Writers from Iraq. Albany: State University of New York Press.

- 2005. More and More Equal: The Literary Works of Sami Michael. Lanham: Lexington Books.

Blanc, Haim. 1964. Communal Dialects in Baghdad. Cambridge, Mass: Harvard University.

Blau, Joshua. 1981. The Emergence and Linguistic Background of Judaeo-Arabic: A Study of the Origins of Middle Arabic: Humanities Pr. 
Bullock, Barbara E., \& Almeida J. Toribio, eds. 2009. The Cambridge Handbook of Linguistic Code-Switching. Cambridge handbooks in linguistics. Cambridge, New York: Cambridge University Press.

Callahan, Laura. 2004. Spanish/English Codeswitching in a Written Corpus. Studies in bilingualism. Amsterdam: John Benjamins Pub.

Coupland, Nikolas. 2001a. "Dialect Stylization in Radio Talk." Language in Society 30: $345-75$.

_ 2001b. "Stylization, Authenticity and TV News Review." Discourse Studies 3: 413-42.

Gardner-Chloros, Penelope. 2009. Code-Switching. Cambridge, UK: Cambridge University Press.

Grosjean, François. 2010. Bilingual: Life and Reality. Cambridge, Mass: Harvard University Press.

Grosjean, François, Ping Li, \& Ellen Bialystok. 2013. The Psycholinguistics of Bilingualism. Hoboken: Wiley-Blackwell/John Wiley \& Sons.

Hary, Benjamin H. 1992. Multiglossia in Judeo-Arabic, with an Edition, Translation and Grammatical Study of the Cairene Purim Scroll. Leiden, New York, Koln: Brill.

Haugen, Einar. 1953. The Norwegian Language in America: A Study in Bilingual Behavior Dialects of Norwegian. Philadelphia: University of Pennsylvania press.

Heinrichs, Hans-Jürgen. 1992. Sprich Deine Eigene Sprache, Afrika! Von der Négritude zur afrikanischen Literatur der Gegenwart. Berlin: D. Reimer.

Hever, Hannan. 2002. Producing the Modern Hebrew Canon: Nation Building ad Minority Discourse. New York: New York University Press.

- 2007. Narrtive and the Nation. Tel Aviv: Resling (in Hebrew). 
Hever, Hannan, Yehouda A. Shenhav, \& Pnina Motzafi-Haller. 2002. Mizrahim in Israel. Jerusalem: The Van Leer Jerusalem Institute (in Hebrew).

Ibhawaegbele, Faith O., and Justina . Edokpayi. 2012. "Code-Switching and CodeMixing as Stylistic Devices in Nigerian Prose Fiction: A Study of Three Nigerian Novels." Research on Humanities and Social Sciences 2 (6): 12-19.

Jakobson, Roman. 1960. "Closing Statement: Linguistics and Poetics." In Style in Language, edited by Thomas A. Sebeok. Cambridge, Massachusetts.

Jakobson, Roman, \& Morris Halle. 1956. Fundamentals of Language. Janua linguarum [Series minor]. 'S-Gravenhage: Mouton.

Jonsson, Carla. 2010. "Functions of Code-Switching in Bilingual Theater: An Analysis of Three Chicano Plays." Journal of Pragmatics 42 (5): 1296-1310.

Kellman, Steven G. 2000. The Translingual Imagination. Lincoln: University of Nebraska Press.

Levy, Lital. 2006. "Self and the City: Literary Representations of Jewish Baghdad." Prooftexts 26 (1): 163-211.

Lipski, John M. 1982. “Spanish-English Language Switching in Speech and Literature: Theories and Models." Bilingual Review / La Revista Biling üe 9 (3): 191-212.

Mansour, Jacob. 1991. The Jewish Baghdadi Dialect: Studies and Texts in the JudeoArabic Dialect of Baghdad. Or-Yehuda: The Babylonian Jewry Heritage Center, the Institute for Research on Iraqi Jewry.

Me'iri, Yehoshu'a. 2006. Echoes of Babylon: Idioms, Sayings and Folklore of the Baghdadi Jews. Jerusalem: Re'uven Mas (in Hebrew/ Judeo-Arabic). 
Michael, Sami. 1974. All Men are Equal - But Some are More. Tel Aviv: Bustan (in Hebrew).

— 1984. "On Being an Iraqi-Jewish Writer in Israel." Prooftexts 4: 23-33.

Montes-Alcala, Cecilia. 2000. "Two Languages, one Pen: Socio-Pragmatic Functions in Written Spanish-English Code-Switching." PhD Thesis, University of California.

—. 2012. "Code-Switching in US-Latino Novels." In Language Mixing and CodeSwitching in Writing: Approaches to Mixed-Language Written Discourse, edited by Mark Sebba, Shahrzad Mahootian, and Carla Jonsson, 68-88. New York: Routledge.

Müller, Heidy M., Anat Feinberg, \& Kolo, Kamal Y. Odisho. 2011. Das Ende des Babylonischen Exils: Kulturgeschichtliche Epochenwende in der Literatur der letzten irakisch-jüdischen Autoren. Wiesbaden: Reichert.

Muysken, Pieter. 2000. Bilingual Speech: A Typology of Code-Mixing. Cambridge, UK, New York: Cambridge University Press.

Myers-Scotton, Carol. 1993. Social Motivations for Codeswitching: Evidence from Africa. Oxford studies in language contact. Oxford: Clarendon Press.

—. 1998. Codes and Consequences: Choosing Linguistic Varieties. New York: Oxford University Press.

Naor, Mordechay. 1986. Immigrants and Transit Camps: 1948-1952. Jerusalem: Yad Yitzhak Ben-Zvi (in Hebrew).

Poplack, Shana. 1980. ""Sometimes I'll Start a Sentence in Spanish Y TERMINO EN ESPAÑOL": Toward a Typology of Code-Switching." Linguistics 18 (7/8): 581-618.

Sebba, Mark, Shahrzad Mahootian, \& Carla Jonsson, eds. 2012. Language Mixing and Code-Switching in Writing: Approaches to Mixed-Language Written Discourse. New York: Routledge. 
Shanon, Benny. 1991. "Faulty Language Selection in Polyglots." Language and Cognitive Processes 6 (4): 339-50.

Snir, Reuven. 2005a. Arabness, Jewishness, Zionism: A Clash of Identities in the Literature of Iraqi Jews. Jerusalem: Yad Yitzhak Ben-Zvi (in Hebrew).

—. 2005b. "When Time Stopped: Ishaq Bar-Moshe as Arab-Jewish Writer in Israel." Jewish Social Studies 11 (2): 102-35.

Thomason, Sarah G. 2001. Language Contact. Edinburgh: Edinburgh University Press. Torres, L. 2007. "In the Contact Zone: Code-Switching Strategies by Latino/a Writers." MELUS 32 (1): 75-96.

Wright, Chantal. 2010. "Exophony and Literary Translation: What it Means for the Translator when a Writer Adopts a New Language." Target, International Journal of Translation Studies 22 (1): 22-39.

Yona-Swery, Gila. 1995. The Dictionary of Iraqi Jewish Dialect. Jerusalem:

Association of Jewish Academics from Iraq (in Hebrew/Judeo-Arabic).

Yosef, David. 2005. The Mother-Tongue: A Nostalgic Dictionary of Spoken Iraqi Judeo-Arabic. Tel Aviv: Y. David (in Hebrew/ Judeo-Arabic).

Zeidel, Ronen. 2009. “A Question of Language and Audience: On the Possibility of "Iraqi Novels" in Hebrew." Hebrew Studies 50: 229-43. 


\section{Appendixes}

The two appendixes contain lists of the Arabic codes extracted from the three

Hebrew novels covering both cases of code-switching as suggested by the study, i.e.

Hard-Access Code-Switching and Easy-Access Code-Switching. The extracts are arranged alphabetically with the frequency of each item and the reference.

\begin{tabular}{|c|c|c|c|c|c|}
\hline \multicolumn{2}{|l|}{ Ha-Ma'barah } & \multicolumn{2}{|c|}{ Shavim we-shavim yoter } & \multicolumn{2}{|c|}{ Tarnegol kapparot } \\
\hline Extracts & Reference & Extracts & Reference & Extracts & Reference \\
\hline אה & $159 ; 163$ & אבו & $28 ; 48$ & אהוות ערב & 93 \\
\hline אהלן באבו-יעגוב & $198 ; 198$ & אבן-אל-מאניוקה & 191 & אהלן וסהלן & 19 \\
\hline אהלן באבו-סבאח & 9 & 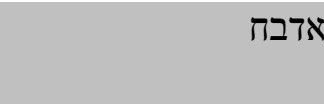 & $\begin{array}{l}9 ; 9 ; 9 ; 11 ; \\
11 ; 11\end{array}$ & אוהו & $11 ; 12$ \\
\hline אהלן בחיים & 99 & אה & $\begin{array}{l}13 ; 17 ; 17 \\
34 ; 35 ; 35 ; \\
41 ; 104 ; \\
119\end{array}$ & 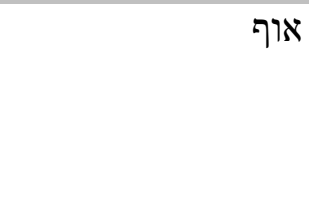 & $152 ; 152$ \\
\hline 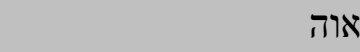 & 70 & אהלאן-וסאהלאן & 118 & אחרא דין בוק & 14 \\
\hline 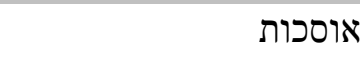 & 162 & אט-טאריק מקטועה & 191 & אל -צ'איחנה & 152 \\
\hline אינשאללה & $60 ; 133$ & איי & $\begin{array}{l}21 ; 37 ; \\
119 ; 166\end{array}$ & אללה אכבר & $69 ; 69 ;$ \\
\hline אל-חראמי & 113 & אילחמדו-לאיללה & 195 & הקללה יבארכ פיכ על & 148 \\
\hline 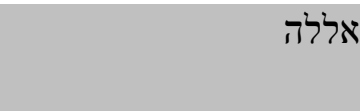 & $\begin{array}{l}33 ; 35 ; \\
181\end{array}$ & אינשאללה & $40 ; 78$ & אלתכ'יה & 150 \\
\hline אל-עמארה & 51 & 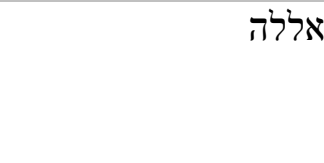 & $\begin{array}{l}21 ; 23 ; 37 \\
38 ; 84 ; \\
105 ; 135\end{array}$ & אסלמה עליך & $\begin{array}{l}39 ; 39 ; \\
140\end{array}$ \\
\hline א-נאצר & 9 & אנא מאגרוח & 191 & בלאש & 77 \\
\hline 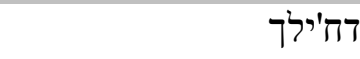 & 63 & אצילה & 107 & ג'ארה & 117 \\
\hline הא & $13 ; 191$ & אשרע! אשרע! & 191 & גוג'ה & $40 ; 40$ \\
\hline ואללה & $76 ; 114$ & באקשיש & 44 & גרוש & 151 \\
\hline
\end{tabular}


Appendix 1. Hard-Access Code-Switching in the corpora

\begin{tabular}{|c|c|c|c|c|c|c|}
\hline \multicolumn{2}{|l|}{ Ha-Mabarah } & \multicolumn{3}{|c|}{ Shavim we-shavim yoter } & \multicolumn{2}{|c|}{ Tarnegol kapparot } \\
\hline Extracts & Reference & Extracts & & Reference & Extracts & Reference \\
\hline & $\begin{array}{l}152 ; 164 ; \\
187 ; 200 ; \\
201\end{array}$ & & & & & \\
\hline 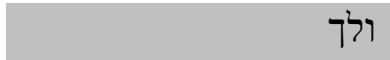 & 20 & & 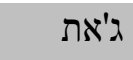 & 26 & דחילק & 156 \\
\hline חביבי & $\begin{array}{l}31 ; 137 ; \\
162 ; 164 ; \\
201\end{array}$ & & 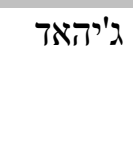 & 118 & ה"לפה & 152 \\
\hline חבאב-לאגיי חסיין א-נעימי & 8 & & דחילאק & $\begin{array}{l}31 ; 73 ; \\
130 ; 132\end{array}$ & הג'לאלה & 91 \\
\hline חושו-נא וחלצוני & 85 & & 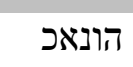 & 191 & 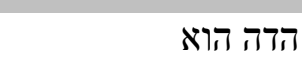 & 58 \\
\hline טאולה & 11 & & היי & 47 & 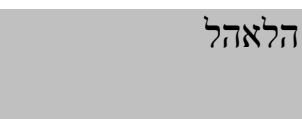 & $\begin{array}{l}110 ; 110 \\
111 ; 111\end{array}$ \\
\hline יא & $8 ; 152$ & & וואללה & $\begin{array}{l}14 ; 22 ; 35 ; \\
48 ; 55 ; 78 ; \\
90 ; 104 ; \\
95 ; 95 ; \\
122\end{array}$ & 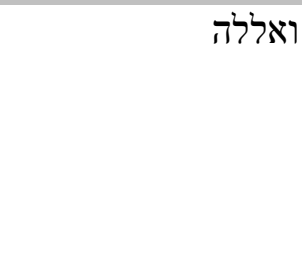 & 40 \\
\hline 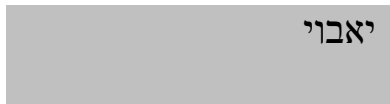 & 29 & & חאבובה & 81 & $\begin{array}{r}\text { חואללה מבסוט, סלים } \\
\text { חים }\end{array}$ & 147 \\
\hline יחרב ביתך & 67 & & 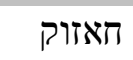 & $78 ; 78$ & 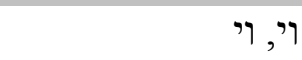 & 78 \\
\hline מבסוט & 164 & & חאראם & 108 & זיפת - - - - 1 & 117 \\
\hline סלאמתך & 126 & & חביבי & 146 & 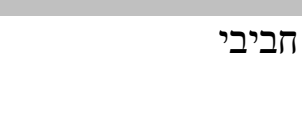 & $\begin{array}{l}26 ; 40 ; \\
136\end{array}$ \\
\hline שיך חסן & 36 & & 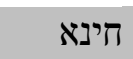 & 195 & חואג'ה & 147 \\
\hline שיך יצחק & 16 & & טפו & 28 & חלס & 77 \\
\hline תפדל & 86 & & יא & $\begin{array}{l}13 ; 14 ; 16 ; \\
17 ; 17 ; 17 \\
18 ; 22 ; 23 \\
24 ; 25 ; 25 ; \\
25 ; 26 ; 29 \\
29 ; 30 ; 34 ; \\
34 ; 37 ; 37 \\
38 ; 38 ; 39 \\
40 ; 41 ; 62 ; \\
62 ; 63 ; 63 ;\end{array}$ & חרא & $55 ; 55$ \\
\hline
\end{tabular}


Appendix 1. Hard-Access Code-Switching in the corpora

\begin{tabular}{|c|c|c|c|c|c|c|c|}
\hline \multirow{2}{*}{$\begin{array}{l}\text { Ha-Ma'barah } \\
\text { Extracts }\end{array}$} & & \multicolumn{3}{|c|}{ Shavim we-shavim yoter } & \multicolumn{3}{|c|}{ Tarnegol kapparot } \\
\hline & Reference & Extracts & & Reference & Extracts & & Reference \\
\hline & & & & $\begin{array}{l}63 ; 73 ; 73 ; \\
74 ; 74 ; 76 ; \\
85 ; 85 ; 85 ; \\
86 ; 90 ; 90 ; \\
90 ; 99 ; \\
101 ; 102 ; \\
104 ; 105 ; \\
106 ; 106 ; \\
106 ; 106 ; \\
106 ; 106 ; \\
106 ; 106 ; \\
106 ; 106 ; \\
106 ; 106 ; \\
106 ; 106 ; \\
106 ; 106 ; \\
106 ; 106 ; \\
106 ; 106 ; \\
106 ; 106 ; \\
106 ; 108 ; \\
196\end{array}$ & & & \\
\hline & & & יא-אבא & $\begin{array}{l}13 ; 13 ; 13 ; \\
24 ; 33 ; 38 \\
38 ; 39 ; 39 \\
90\end{array}$ & & טיז & $24 ; 25 ; 51$ \\
\hline & & & יא-אבו & $\begin{array}{l}13 ; 17 ; 17 \\
17 ; 21 ; 35 ; \\
72 ; 72 ; \\
118 ; 119\end{array}$ & & יא & $\begin{array}{l}19 ; 18 ; 55 ; \\
101 ; 106 ; \\
130 ; 196\end{array}$ \\
\hline & & & 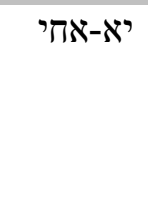 & 103 & & יא אללה & $\begin{array}{l}18 ; 24 ; 25 ; \\
25 ; 32 ; 39 ; \\
51 ; 68 ; 68 ; \\
77 ; 173\end{array}$ \\
\hline & & & יא-אללה & $\begin{array}{l}32 ; 104 ; \\
142\end{array}$ & & יא אללה, & $123 ; 124$ \\
\hline & & & יא-אללה & 13 & & יא עיני & 174 \\
\hline & & & יא-בני & $\begin{array}{l}24 ; 25 ; 33 \\
35 ; 38 ; 39\end{array}$ & & 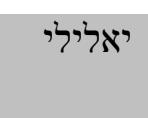 & 129 \\
\hline
\end{tabular}


Appendix 1. Hard-Access Code-Switching in the corpora

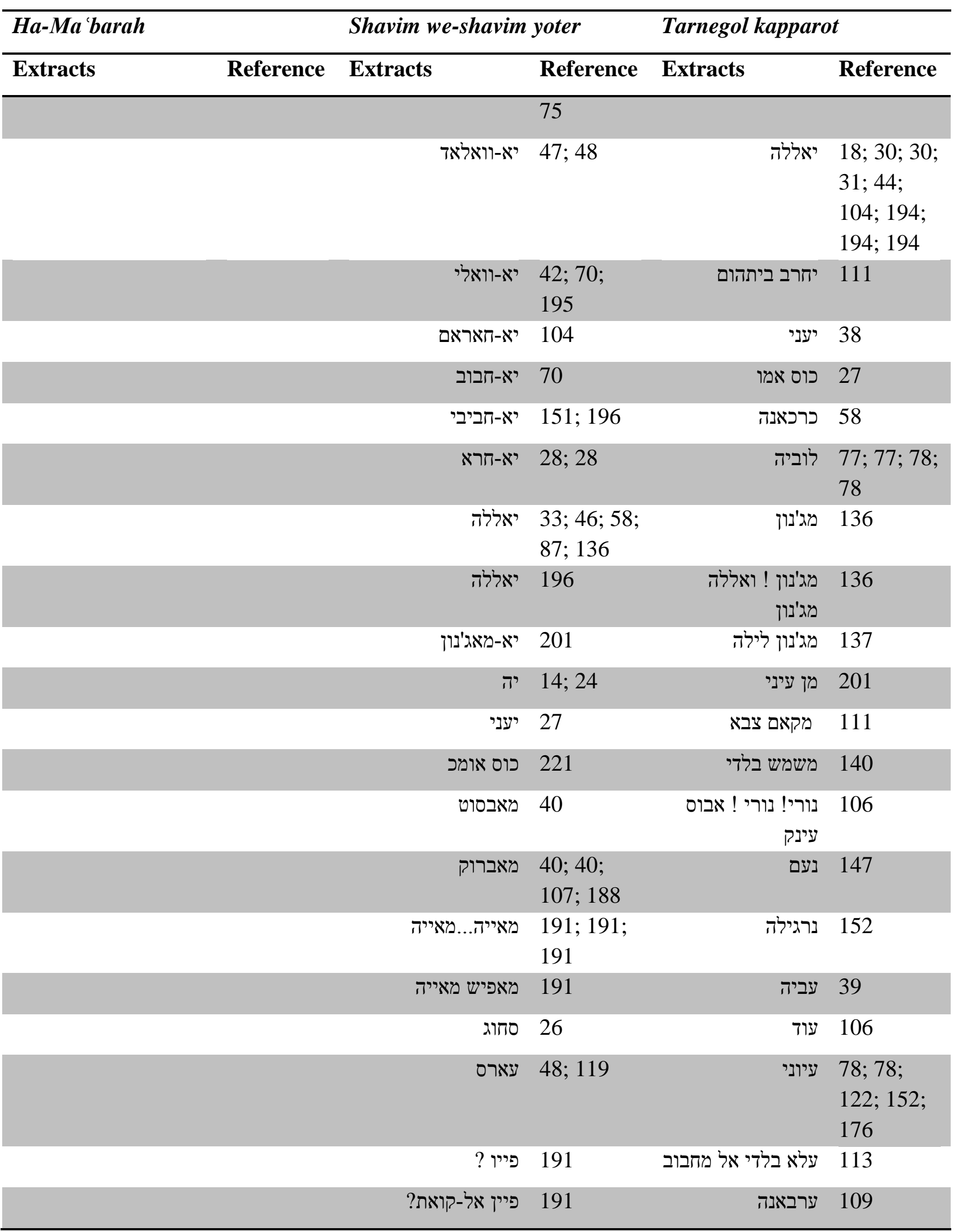


Appendix 1. Hard-Access Code-Switching in the corpora

\begin{tabular}{|c|c|c|c|c|c|}
\hline \multirow{2}{*}{$\begin{array}{l}\text { Ha-Ma'barah } \\
\text { Extracts }\end{array}$} & \multicolumn{3}{|c|}{ Shavim we-shavim yoter } & \multicolumn{2}{|l|}{ Tarnegol kapparot } \\
\hline & Reference & Extracts & Reference & Extracts & Reference \\
\hline & & קובה & $71 ; 72$ & פיתה & $77 ; 152$ \\
\hline & & קובה-בורגול & 188 & פנאג'ין & 148 \\
\hline & & שארמוטה & 24 & קבב & 193 \\
\hline & & תעאל לאהון & 231 & שארע אל-רשיד & 39 \\
\hline & & תעאל-מן-הנה & $191 ; 191$ & ששליק & 193 \\
\hline & & תפאדאל & $118 ; 245$ & 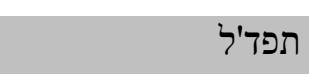 & 152 \\
\hline & & תפדאלי & $\begin{array}{l}40 ; 114 \\
188\end{array}$ & תקאסים & 107 \\
\hline & & & & תרבוש & 39 \\
\hline
\end{tabular}




\begin{tabular}{|c|c|c|c|c|c|}
\hline \multicolumn{6}{|c|}{ Appendix 2. Easy-Access Code-Switching in the corpora } \\
\hline \multicolumn{2}{|l|}{ Ha-Ma barah } & \multicolumn{2}{|c|}{ Shavim we-shavim yoter } & \multicolumn{2}{|c|}{ Tarnegol kapparot } \\
\hline Extracts & Reference & Extracts & Reference & Extracts & Reference \\
\hline אבו-יעגוב & $84 ; 198$ & - & - & אבוס עינק & 201 \\
\hline אבו-ע'איב & $23 ; 152$ & & & אוסכות & 125 \\
\hline 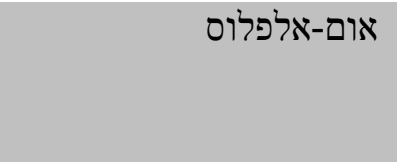 & 28 & & & עחבין מא הום & 85 \\
\hline נאבל אחט אל-חאבל באל- & 52 & & & אכון ממנון & 148 \\
\hline אלקווה & 30 & & & בס ניפהמהא חילוה & 107 \\
\hline א-שבאב אל-קאומי & 11 & & & מג'רפואד אל & 180 \\
\hline באיזן אללה אינתצרנא & 9 & & & אנהג'ם ביתק & 79 \\
\hline ג'האר יאק & 145 & & & אנףף נאר ואנף & 87 \\
\hline הא לך, נזאח & 64 & & & עידק אהוות מע הל & 147 \\
\hline הגדיש & 156 & & & ג'וז מנו & 80 \\
\hline 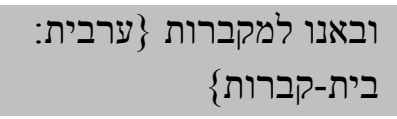 & 119 & & & גחבה - - & $124 ; 180$ \\
\hline ולא יהימך אבו ג'מיל & 108 & & & ולאד אללה & 66 \\
\hline חיים אל-כאתב & 53 & & & חפלה - ( - 1 & $106 ; 129$ \\
\hline ח'יר אינשאללה & $134 ; 186$ & & & טיא הלי אל- עיאם חינו & 38 \\
\hline חמדילה עסלאמה & $125 ; 188$ & & & יא סמרה רוחי & 108 \\
\hline יום אלעינדך & 33 & & & ג'בתינה יא ימה ללט'ים & 57 \\
\hline יזיד פדלכום & 86 & & & כיף אלאהווה? & 148 \\
\hline כובות & 180 & & & כל טיז יסוה' & 19 \\
\hline
\end{tabular}




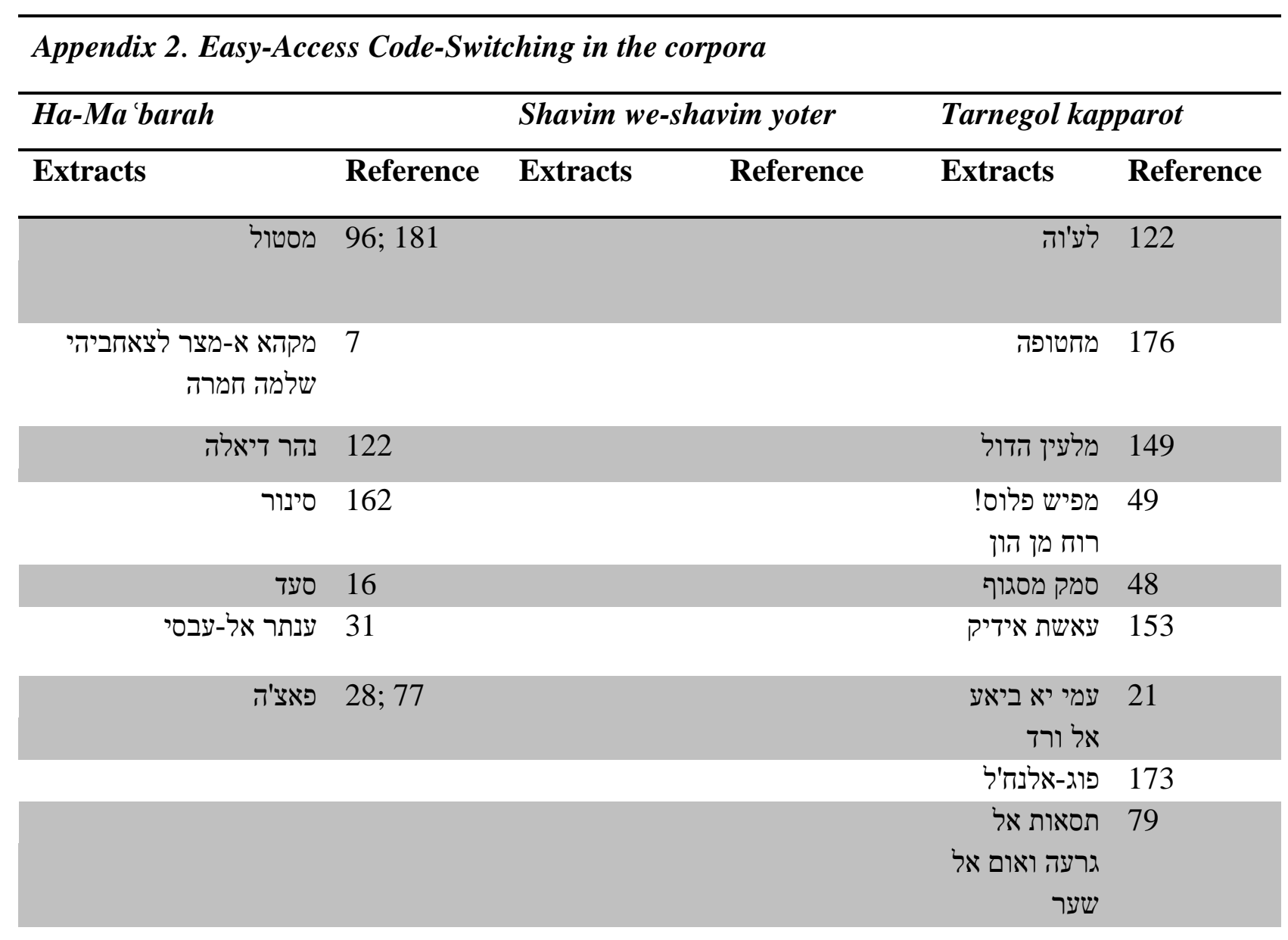

